\title{
Livestock Antibiotic Effects on Nitrification, Denitrification, and Microbial Community Composition in Soils
}

\author{
Sagarika Banerjee, Elisa D’Angelo* \\ Department of Plant and Soil Sciences, University of Kentucky, Lexington, USA. \\ Email: *edangelo@uky.edu
}

Received June $6^{\text {th }}, 2013$; revised July $6^{\text {th }}, 2013$; accepted July $13^{\text {th }}, 2013$

Copyright (C) 2013 Sagarika Banerjee, Elisa D'Angelo. This is an open access article distributed under the Creative Commons Attribution License, which permits unrestricted use, distribution, and reproduction in any medium, provided the original work is properly cited.

\begin{abstract}
The broiler (Gallus gallus domesticus) industry in the United States and several other countries routinely includes subtherapeutic levels of antibiotics such as roxarsone, virginiamycin, and bacitracin in the feed to improve bird growth yields. Large fractions of the antibiotics fed to the birds are excreted in manure (litter), which is often applied to soils to improve fertility. Some concerns with this practice are antibiotic-induced alterations in microbially-mediated nutrient cycling, which could influence plant productivity and environmental quality. To investigate this possibility, a series of lab experiments were conducted to determine the effects of increasing levels of the three livestock antibiotics on nitrification, denitrification, and microbial community composition (fatty acid methyl ester profiles) of soils collected along a catena. Roxarsone and virginiamycin significantly influenced microbial community composition and inhibited nitrification in the soils, but only at levels that were several-fold higher than expected in poultry litter-applied soils. Bacitracin did not affect microbial growth, microbial community composition, or nitrification at any concentration tested (up to $500 \mathrm{mg} \cdot \mathrm{kg}^{-1}$ ). None of the antibiotics influenced denitrification at environmentally-relevant concentrations. Amounts of antibiotics in soil solution were greatly reduced by sorption, which followed Freundlich models in the concentration range of $1-500 \mathrm{mg} \cdot \mathrm{L}^{-1}$. Results from this study indicated that addition of roxarsone, virginiamycin, or bacitracin to these soils at environmentally-relevant concentrations would not likely impact microbial community composition, nitrification or denitrification due to intrinsic resistance/insensitivity of microorganisms to these antibiotics and reductions in the bioavailable amounts due to sorption by soil surfaces.
\end{abstract}

Keywords: Bacitracin; Roxarsone; Virginiamycin; Sorption; Antibiotic Resistance; Fatty Acid Methyl Ester

\section{Introduction}

Millions pounds of antibiotics are used in animal husbandry for therapeutic and sub-therapeutic uses in the US and many other countries [1-3]. At sub-therapeutic levels, antibiotics are believed to increase animal growth yields by controlling microbial populations in the gut, and thus reducing toxin levels and competition for essential nutrients and growth factors [4-6]. The most commonly used antibiotics in poultry feed are bacitracin, roxarsone, and virginiamycin, which are fed to birds at concentrations 4 - 55, 25 - 50, and $5-22 \mathrm{mg} \cdot \mathrm{kg}^{-1}$ feed, respectively [7].

Between $30 \%$ and $90 \%$ of antibiotics fed to animals are excreted in animal feces and urine $[3,8]$. Thus, when

\footnotetext{
*Corresponding author.
}

manure is applied to land, antibiotics are also added to soil and surrounding environments [2,8-10]. Some concerns with widespread distribution of antibiotics in the environment are alterations in soil microbial communities and nutrient cycles in soils, which have been observed in numerous studies [11-16]. Examples include reductions in total and active cell counts in forest soils by oxytetracycline and penicillin [11], changes in relative abundance of bacteria, fungi, and protozoa in agricultural soils by tylosin [12], accelerated carbon mineralization by chlortetracycline and oxytetracycline [13], reductions in soil respiration rates by sulfamethoxazole, sulfamethazine and trimethoprim [14], and inhibition of $\mathrm{Fe}$ (III) reduction and substrate-induced respiration rates in soils by sulfapyridine and oxytetracycline [15]. To our 
knowledge, there are no published reports on the effects of bacitracin, virginiamycin, or roxarsone on microbial community composition, nitrification, or denitrification in soils, even though these are among the most commonly used livestock antibiotics, and these $\mathrm{N}$ transformations govern $\mathrm{N}$ availability and transport in soils.

In soils, antibiotic bioavailability and effects on microorganisms are likely to be influenced by sorption with clay minerals, organic matter, and other soil surfaces, which can be further influenced by $\mathrm{pH}$, redox conditions, and ionic strength of the soil solution $[17,18]$. Thus, evaluations of antibiotic effects and exposure levels in soils should take into account the extent of these interactions, which can be high soil specific.

The objectives of this study were to determine 1) levels at which three commonly used livestock antibiotics (bacitracin, virginiamycin, and roxarsone) have adverse effects on nitrification and denitrification potential in soils; 2) effects of antibiotics on soil microbial community structure; and 3) importance of sorption in affecting antibiotic bioavailability to soil microorganisms.

\section{Materials and Methods}

\subsection{Soil Collection}

Soil samples ( 0 - $5 \mathrm{~cm}$ depth) were collected at three topographic positions that represented the shoulder $(273 \mathrm{~m}$ above sea level), backslope $(271 \mathrm{~m})$ and toeslope $(270 \mathrm{~m})$ over a distance of $20 \mathrm{~m}$ of a tall fescue field (overall $\sim 15 \%$ topographic gradient) located at the University of Kentucky Spindletop Farm in Fayette County, Kentucky in March, 2009. At each of the three elevations, three stations located $10 \mathrm{~m}$ apart were set up in a square grid pattern. At each station, ten soil samples from a one $\mathrm{m}^{2}$ area were collected and composited to represent the soil at that station. The composited samples from the nine stations were sealed in separate plastic bags, transported to the laboratory in an ice chest, and stored at $4^{\circ} \mathrm{C}$ for a maximum of one week before being used in experiments. The soil series at the location was McAfee silty clay loam (Fine, mixed, active, mesic, Mollic Hapludalfs). The area was chosen because it had not received poultry litter or any other amendment for at least 20 years, and it contained gradients in soil moisture, $\mathrm{pH}$, and other characteristics representative of a pasture area where litter would be applied.

\subsection{Soil Property Characterization}

Soil $\mathrm{pH}$ was determined in a soil-water paste (1:1 volume basis) using a calibrated glass electrode and meter. Bioavailable $\mathrm{P}, \mathrm{K}, \mathrm{Ca}, \mathrm{Mg}, \mathrm{Zn}$ in soils were estimated using the Mehlich III extraction test, in which soil $\left(2 \mathrm{~cm}^{3}\right)$ was mixed with $20 \mathrm{~mL}$ Mehlich III extract $(0.2 \mathrm{~N}$ acetic acid, $0.25 \mathrm{~N} \mathrm{NH}_{4} \mathrm{NO}_{3}, 0.015 \mathrm{~N} \mathrm{NH}_{4} \mathrm{~F}, 0.013 \mathrm{~N} \mathrm{HNO}_{3}$, and $0.001 \mathrm{~N}$ EDTA), shaken for 5 minutes, and passed through a Whatman \#2 filter paper [19]. The elements in the filtrate were measured by Inductively Coupled Plasma Spectroscopy (ICP) Varion Vista Pro (Palo Alto, California). Cation exchange capacity (CEC) and base saturation were determined by the $\mathrm{pH} 7$ ammonium acetate method and ICP analysis of extracted cations. Organic carbon in soils was determined by an Elemental Vario Max CNS analyzer (Mt. Laurel, New Jersey). Percentages of sand, silt, and clay in the soils were determined by the Na-hexametaphosphate micropipette method. The above soil properties were determined at the Regulatory Services Soil Testing Laboratory at the University of Kentucky, Lexington, KY. Dissolved organic $\mathrm{C}$ and microbial biomass $\mathrm{C}$ were determined by the chloroform fumigation- $\mathrm{K}_{2} \mathrm{SO}_{4}$ extraction using a Shimadzu TOC 5000 A analyzer (Columbia, MD) [20].

\subsection{Antibiotic Effects on Nitrification}

Antibiotic effects on nitrification were determined by monitoring increases in nitrate and nitrite levels in soils amended with substrate $\left(\left(\mathrm{NH}_{4}\right)_{2} \mathrm{SO}_{4}\right)$ and increasing levels of antibiotics in laboratory microcosms over a period of $5 \mathrm{~d}$. The substrate was added to stimulate nitrification activity, which was found to be critical when evaluating effects of biostatic agents on microbial activities [15].

Before conducting the test, background levels of the nitrification products nitrate and nitrite were removed from soils by washing with deionized and distilled water $(100 \mathrm{~mL})$ for $30 \mathrm{~min}$ in a $250 \mathrm{~mL}$ centrifuge bottle and centrifugation at $2057 \times \mathrm{g}$ for $10 \mathrm{~min}$. The supernatant was discarded and the soils were air-dried in a plastic weigh boat at room temperature for five days before being used in nitrification experiments.

Dried soil was passed through a $4 \mathrm{~mm}$ mesh, and $1 \mathrm{~g}$ soil was added to a $20 \mathrm{~mL}$ vial, and mixed with antibiotic solutions $(5 \mathrm{~mL})$ at one of seven concentrations $(0,0.3,1$, $\left.3,10,30,100 \mathrm{mg} \cdot \mathrm{L}^{-1}\right)$. Antibiotic concentrations on a dry soil mass basis were $0,1.5,5,15,50,150$, and 500 $\mathrm{mg} \cdot \mathrm{kg}^{-1}$. The vials were covered with Breathe-Easy membranes (Research Products International, Mount Prospect, IL) to allow oxygen diffusion and inhibit evaporation, and pre-incubated for $1 \mathrm{~d}$ at $24^{\circ} \mathrm{C}$.

After the $1 \mathrm{~d}$ pre-incubation period, $5 \mathrm{~mL}$ of $25 \mathrm{mg}$ $\left(\mathrm{NH}_{4}\right)_{2} \mathrm{SO}_{4}-\mathrm{N} \mathrm{L}^{-1}$ substrate solution was added to each vial and incubated on an orbital shaker at $200 \mathrm{rpm}$ for $5 \mathrm{~d}$ at $24^{\circ} \mathrm{C}$, to stimulate nitrification activity. Five days after substrate addition, vials were centrifuged at $3214 \times \mathrm{g}$ for $10 \mathrm{~min}$. The supernatant was filtered with a $0.45 \mu \mathrm{m}$ membrane syringe filter and analyzed for $\mathrm{NO}_{3}^{-}$and $\mathrm{NO}_{2}^{-}$by the Greiss colorimetric method adapted to the microplate reader [21]. The experiment was repeated for 
each of the antibiotics, including bacitracin (Sigma, St. Louis, and MO), roxarsone (TCI America, Portland, OR) and virginiamycin (Bioworld, Dublin, $\mathrm{OH}$ ).

The effects of antibiotic concentrations on nitrification was determined by normalization to amounts nitrate + nitrite in the zero-level control soils, as shown in the following equation:

Antibiotic effects on nitrification $=\left(\mathrm{NO}_{3}^{-}+\mathrm{NO}_{2}^{-}\right.$in antibiotic-treated soil $) /\left(\mathrm{NO}_{3}^{-}+\mathrm{NO}_{2}^{-}\right.$in zero level control soil).

Using this equation, values less than, equal to, or greater than one indicated that antibiotic inhibited, had no effect, or promoted nitrification, respectively.

\subsection{Antibiotics Effects on Denitrification}

The effects of antibiotics on denitrification in the soils was determined by monitoring increases in $\mathrm{N}_{2} \mathrm{O}$ gas in anaerobic soils amended with $\mathrm{KNO}_{3}$ and increasing levels of antibiotics using the acetylene blockage technique in laboratory microcosms [22].

Soil ( $3 \mathrm{~g})$ was added to $30 \mathrm{~mL}$ serum bottles, and bottles were sealed with serum stoppers and purged with $\mathrm{N}_{2}$ gas to remove $\mathrm{O}_{2}$. Microorganisms in the soils were exposed to deoxygenated solutions of bacitracin, roxarsone or virginiamycin solutions $(3 \mathrm{~mL})$ at seven concentrations $\left(0,1.5,5,15,50,150\right.$, and $\left.500 \mathrm{mg} \cdot \mathrm{L}^{-1}\right)$ for $5 \mathrm{~d}$ at $24^{\circ} \mathrm{C}$. Antibiotic concentrations on a dry soil mass basis were $0,1.5,5,15,50,150$, and $500 \mathrm{mg} \cdot \mathrm{kg}^{-1}$.

After the $5 \mathrm{~d}$ exposure period, $1 \mathrm{~mL}$ of a deoxygenated $25 \mathrm{mM} \mathrm{KNO}{ }_{3}$ substrate solution were mixed with the soils to stimulate denitrification activity, and $3 \mathrm{~mL}$ acetylene gas (prepared with $\mathrm{CaC}_{2}$ and water) was added to inhibit the conversion of $\mathrm{N}_{2} \mathrm{O}$ to $\mathrm{N}_{2}$ gas. The bottles were incubated on an orbital shaker at $140 \mathrm{rpm}$ for $1 \mathrm{~d}$ at $24^{\circ} \mathrm{C}$. Gas samples from the bottles were analyzed for $\mathrm{N}_{2} \mathrm{O}$ gas on a Shimadzu 14 A gas chromatograph equipped with an ${ }^{63} \mathrm{Ni}$ electron capture detector $\left(340^{\circ} \mathrm{C}\right)$, Porapak Q column $(1.82 \mathrm{~m}$ and $3.175 \mathrm{~mm})\left(35^{\circ} \mathrm{C}\right)$, and injector $\left(45^{\circ} \mathrm{C}\right)$ with nitrogen carrier gas. Calibrations were made using a Scotty Specialty $448 \mathrm{~N}_{2} \mathrm{O}$ gas standard (Plumsteadville, PA).

The effect of antibiotics on denitrification at each concentration was determined by normalizing to amounts of $\mathrm{N}_{2} \mathrm{O}$ produced in the zero-level controls.

\subsection{Antibiotic Effects on Microbial Community Composition}

The effects of antibiotics on microbial community composition in the soils was determined by analyzing changes in 59 ester-linked fatty acid methyl esters (FAMEs) in soils exposed to increasing levels of antibiotics in lab microcosms. Soil $(25 \mathrm{~g})$ was passed through a
$4 \mathrm{~mm}$ mesh and mixed with antibiotic solution $(2 \mathrm{~mL})$ at various bacitracin, roxarsone or virginiamycin concentrations $\left(0,1\right.$, and $100 \mathrm{mg}$ antibiotic $\mathrm{kg}^{-1}$ soil) in a $50 \mathrm{~mL}$ beaker. The beakers were covered with parafilm to reduce evaporation, and were incubated in the dark for up to 4 weeks. After 1 and 4 weeks, $5 \mathrm{~g}$ of sample was removed from the beakers and stored at $-80^{\circ} \mathrm{C}$ in plastic bags until FAME analysis.

The FAMEs were extracted using the alkaline methanolysis ester-linked extraction method [23]. Soil (3 g) was vortexed with $15 \mathrm{~mL}$ of freshly prepared $0.2 \mathrm{M}$ $\mathrm{KOH}$ in methanol for $20 \mathrm{~s}$ in a $35 \mathrm{~mL}$ glass centrifuge tube. The tubes were placed in a water bath for one $\mathrm{h}$ set at $37^{\circ} \mathrm{C}$, and vortexed every 10 minutes for 10 seconds during this period. After 1 hour, $2.5 \mathrm{~mL}$ of $1 \mathrm{M}$ acetic acid was added to each tube to neutralize the $\mathrm{pH}$. Ten $\mathrm{mL}$ hexane was mixed with tube contents by vortexing. The tubes were centrifuged for 20 minutes at $329 \times$ g. Five $\mathrm{mL}$ of the top hexane phase that contained the FAMEs was transferred to a $16 \mathrm{~mL}$ glass tube and was gently evaporated to almost dryness with $\mathrm{N}_{2}$ gas. The FAMEs were dissolved in $0.2 \mathrm{~mL}$ of $1: 1$ hexane:methyl-tert butyl ether and transferred to an auto-sampler gas chromatography vial with teflon-lined cap. The FAMEs were analyzed using a Shimadzu 14 A gas chromatograph fitted with a flame ionization detector $\left(260^{\circ} \mathrm{C}\right)$, splitless injector $\left(250^{\circ} \mathrm{C}\right)$ and $\mathrm{Rtx}^{\circledR}-1$ fused silica column (1\% diphenyl - 99\% dimethyl polysiloxane, $30 \mathrm{~m}$ length by $0.32 \mathrm{~m}$ id and $0.25 \mu \mathrm{m}$ thickness). Helium (He) was used as the carrier gas. The oven temperature program was $80^{\circ} \mathrm{C}$ held for $0.5 \mathrm{~min}$, ramped up to $250^{\circ} \mathrm{C}$ at $3^{\circ} \mathrm{C} \cdot \mathrm{min}^{-1}$, and then held at $250^{\circ} \mathrm{C}$ for $10 \mathrm{~min}$. The identity and concentrations of individual FAMEs was determined using standards obtained from Supelco (Bellefonte, PA).

Standard fatty acid nomenclature was used in this study $[23,24]$. For example, 18:1 $\omega 5$ describes a fatty acid with 18 carbon chain length with one double bond located on the fifth carbon from the methyl end of the chain. In this paper, all double bonds are in the "cis" conformation, unless indicated otherwise indicated by a "t" suffix that denotes a "trans" conformation. Branching positions are represented by prefixes "a" (anteiso), "b" (branched), "i" (iso), "Me" (methyl group), and "cy" (cyclopropane). Different FAMEs were assumed to represent various microbial groups as follows: 1) terminally-branched FAMEs represent Gram-positive bacteria; 2) monounsaturated FAMEs represent aerobic eukaryotes and Gram-negative bacteria; 3) mid-chain branched, saturated and branched and monounsaturated FAMEs represent sulfate-reducing and other anaerobic bacteria, as well as actinomycetes; 4) polyunsaturated FAMEs and those with larger than $20 \mathrm{C}$ chain long are indicators of fungi and some micro-eukaryotes. 


\subsection{Sorption Effects on Antibiotic Bioavailability}

The role of sorption in reducing the bioavailability of bacitracin, roxarsone and virginiamycin was determined by comparing the growth of soil microorganisms in cultures exposed to solutions with increasing concentrations of antibiotics before treatment with soil (BT) and after treatment with soil (AT). Microbes for the bioassay were extracted from a bulk soil that was obtained by combining soil (1 g) from each of the nine sites (total $9 \mathrm{~g}$ ) with $90 \mathrm{~mL}$ Luria-Bertani (LB) broth nutrient solution in a $250 \mathrm{~mL}$ centrifuge bottle. The bottle was shaken on a horizontal shaker for $2 \mathrm{~h}$ and centrifuged at $100 \times g$ for $15 \mathrm{~min}$. The supernatant containing the microorganisms was passed through $20 \mu \mathrm{m}$ pore filter paper to remove particles that remained after centrifugation, and was stored in the refrigerator until used in bioassays the following day.

As indicated before, BT and AT solutions were used in the bioassays. The BT antibiotic solutions consisted of bacitracin, roxarsone, or virginiamycin prepared at $0,1.5$, $5,15,50,150$, and $500 \mathrm{mg} \cdot \mathrm{L}^{-1}$. The AT solutions were the same as the BT solutions, except that antibiotics were first equilibrated with soil to allow sorption to take place before exposing organisms to the antibiotics remaining in solution. To prepare the AT antibiotic solutions, $1.5 \mathrm{~mL}$ antibiotic solution at one of the seven levels were equilibrated with oven-dried and sieved $(2 \mathrm{~mm})$ soil $(0.5 \mathrm{~g})$ in $2-\mathrm{mL}$ microtubes on a horizontal shaker for $4 \mathrm{~h}$. The $4 \mathrm{~h}$ equilibration time was selected to allow sorption to take place and also reduce the chances for antibiotic degradation. After this period, microtubes were centrifuged at $9400 \times \mathrm{g}$ for $5 \mathrm{~min}$, filtered with $0.45 \mu \mathrm{m}$ membrane, and stored at $4^{\circ} \mathrm{C}$ until used in microbial growth bioassay tests and determinations of antibiotic concentrations.

The microbial growth bioassay was conducted using the BT and AT antibiotic solutions in triplicate as follows. The BT or AT antibiotic solutions $(0.75 \mathrm{~mL})$ were amended with $0.25 \mathrm{~mL}$ of bacterial stock solution and $0.25 \mathrm{~mL}$ of LB broth (to stimulate microbial growth) in a $2 \mathrm{~mL}$ microtube. The final antibiotic concentrations in the BT microtubes were $0,0.9,3.0,9,30,90,300 \mathrm{mg} \cdot \mathrm{L}^{-1}$; concentrations in the AT solutions were expected to be lower as a result of sorption. The bacteria and antibiotic mixtures were incubated overnight on an orbital shaker at $250 \mathrm{rpm}$ at $28^{\circ} \mathrm{C}$. After 1 and $2 \mathrm{~d}$, the tubes were vortexed, and cell densities were measured at $600 \mathrm{~nm}$ using a microplate reader (BioTek, Horshman, PA).

The effect of antibiotics at the various concentrations on microbial growth in the nutrient solutions was determined from the equation:

Antibiotic effects on microbial growth $=$ (cell growth with antibiotic)/(cell growth without antibiotic).

The importance of sorption in reducing antibiotic bioavailability was determined by comparing microbial growth in the BT and AT solutions, as shown in the equation:

Sorption effects on antibiotic bioavailability $=$ (cell growth in AT solution)/(cell growth in BT solution).

Values less than one reflect the extent that sorption reduced antibiotic bioavailability in the AT treatment.

To determine the extent of antibiotic sorption by the soils, the concentrations of antibiotics in AT solutions were determined using Shimadzu high performance liquid chromatograph equipped with a UV-Vis detector set at $220 \mathrm{~nm}$ and reverse phase Phenomenex Synergi $4 \mathrm{u}$ Hydro-RP 80 A column (Torrance, CA). Different proportions of $0.3 \%$ formic acid solution and acetonitrile were used as mobile phases for the various antibiotics. For roxarsone analysis, the run time was 5 min using a mobile phase of $10 \%$ acetonitrile and $90 \%$ formic acid solution. For bacitracin analysis, the run time was $23 \mathrm{~min}$ using an initial mobile phase of 5\% acetonitrile: $95 \%$ formic acid solution that was ramped up to $60 \%$ acetonitrile: $40 \%$ formic acid solution over $10 \mathrm{~min}$, and returned to $5 \%$ acetonitrile: $95 \%$ formic acid solution over $13 \mathrm{~min}$. For virginiamycin analysis, the run time was $20 \mathrm{~min}$ using an initial mobile phase of $40 \%$ acetonitrile: $60 \%$ formic acid solution that was ramped to $60 \%$ acetonitrile: $40 \%$ formic acid solution over $8 \mathrm{~min}$, and returned to $40 \%$ acetonitrile: $60 \%$ formic acid solution over $12 \mathrm{~min}$. The amounts of antibiotic retained by sorption were determined from the difference in amounts of antibiotics in the BT and AT solutions prior to the use in the bioassay experiments.

\subsection{Statistical Analysis}

The effects of antibiotic levels on nitrification, denitrification, FAMEs, and microbial growth were determined by ANOVA and Tukey's Honestly Significant Difference test (HSD), at a significance level of $p=0.05$. All the statistical analyses were performed using STAGRAPHICS Plus Version 5.0 software (Manugistics, Rockville, MD).

\section{Results}

\subsection{Chemical Properties of Soils}

There were significant differences in several chemical properties of soils along the topographic gradient (Table 1). Soil pH ranged between 5.85 and 6.68 , and was significantly higher in the toeslope soils than in the shoulder and backslope soils $(\mathrm{p}=0.001)$. Mehlich III K ranged between 139 and $376 \mathrm{mg} \cdot \mathrm{kg}^{-1}$, and was significantly higher in the backslope soils than in the shoulder and toeslope soils $(p=0.003)$. Mehlich III Ca ranged be- 
Table 1. Chemical properties of soils at the shoulder (273 $\mathrm{m}$ above sea level), backslope (271 $\mathrm{m}$ ) and toeslope (270 $\mathrm{m})$ positions along a topographic gradient. Each value represents the mean of three field replicates. Values followed by different letters are significantly different at a p-value of 0.05 .

\begin{tabular}{|c|c|c|c|c|}
\hline \multicolumn{5}{|c|}{ Soil elevation (m, above sea level) } \\
\hline Soil Property & 273 & 271 & 270 & p-value \\
\hline $\mathrm{pH}$ & $5.85^{\mathrm{a}}$ & $5.86^{\mathrm{a}}$ & $6.68^{\mathrm{b}}$ & 0.001 \\
\hline Mehlich III P (mg·kg $\left.{ }^{-1}\right)$ & 208 & 257 & 194 & 0.600 \\
\hline Mehlich III K (mg $\left.\cdot \mathrm{kg}^{-1}\right)$ & $204^{\mathrm{a}}$ & $376^{\mathrm{b}}$ & $139^{\mathrm{a}}$ & 0.003 \\
\hline Mehlich III Ca (mg $\left.\cdot \mathrm{kg}^{-1}\right)$ & $1709^{\mathrm{a}}$ & $1650^{\mathrm{a}}$ & $2940^{\mathrm{b}}$ & 0.002 \\
\hline Mehlich III Mg (mg.kg $\left.{ }^{-1}\right)$ & 147 & 196 & 129 & 0.065 \\
\hline Mehlich III Zn (mg·kg $\left.{ }^{-1}\right)$ & 2 & 4 & 4 & 0.200 \\
\hline Mehlich III Mn (mg $\left.\cdot \mathrm{kg}^{-1}\right)$ & 102 & 90 & 115 & 0.655 \\
\hline Mehlich III Al (mg $\left.\cdot \mathrm{kg}^{-1}\right)$ & 1054 & 1052 & 840 & 0.068 \\
\hline Organic Carbon (\%) & 3.9 & 3.9 & 4.6 & 0.354 \\
\hline Dissolved organic $\mathrm{C}\left(\mathrm{mg} \cdot \mathrm{C} \cdot \mathrm{kg}^{-1}\right)$ & $148^{\mathrm{a}}$ & $168^{\mathrm{a}}$ & $233^{\mathrm{b}}$ & 0.001 \\
\hline Microbial C $\left(\mathrm{mg} \cdot \mathrm{C} \cdot \mathrm{kg}^{-1}\right)$ & $390^{\mathrm{ab}}$ & $269^{\mathrm{a}}$ & $494^{\mathrm{b}}$ & 0.012 \\
\hline Total N (\%) & 0.32 & 0.39 & 0.36 & 0.432 \\
\hline Sand $(\%)$ & 14 & 15 & 16 & 0.764 \\
\hline Silt (\%) & 69 & 71 & 68 & 0.827 \\
\hline Clay (\%) & 17 & 14 & 17 & 0.733 \\
\hline Base Saturation (\%) & $59^{\mathrm{a}}$ & $55^{\mathrm{a}}$ & $80^{\mathrm{b}}$ & 0.012 \\
\hline Cation Exchange Capacity (meq $100 \mathrm{~g}^{-1}$ ) & 20 & 23 & 24 & 0.064 \\
\hline
\end{tabular}

tween 1650 and $2940 \mathrm{mg} \cdot \mathrm{kg}^{-1}$, and was significantly higher in the toeslope soils than in the shoulder and backslope soils $(\mathrm{p}=0.002)$. Percent base saturation of the soils ranged between 55 and $80 \%$, and was significantly higher in the toeslope soils than in the backslope and shoulder soils $(p=0.012)$. Dissolved organic $C$ and microbial $\mathrm{C}$ were significantly higher in the toeslope than other elevations ( $\mathrm{p}=0.001$ and 0.012 , respectively).

\subsection{Antibiotic Effects on Nitrification and Denitrification}

Nitrate + nitrite in the control soil (without antibiotics) increased from an initial average concentration of $0 \mathrm{mg}$ $\mathrm{N} \cdot \mathrm{kg}^{-1}$ at the start of the experiment to $28 \pm 15$ $\mathrm{mg} \cdot \mathrm{N} \cdot \mathrm{kg}^{-1}$ in $5 \mathrm{~d}$, which indicated that experimental conditions were conducive to nitrification activity.

Nitrate + nitrate produced in the bacitracin-treated soils was not significantly different than controls at any concentration tested (up to $500 \mathrm{mg} \cdot \mathrm{kg}^{-1}$ ), but was significantly lower in roxarsone-amended soils at $>150$ $\mathrm{mg} \cdot \mathrm{kg}^{-1}$ in all soils, and was significantly lower in virginiamycin-treated soils at $>15 \mathrm{mg} \cdot \mathrm{kg}^{-1}$ in the shoulder and backslope, and at $>150 \mathrm{mg} \cdot \mathrm{kg}^{-1}$ in the toeslope (Figures 1(a)-(c)).

Nitrous oxide produced in the control soils rapidly increased from an initial value of $0 \%$ to $0.5 \% \pm 0.1 \mathrm{~N}_{2} \mathrm{O}$ of the gas headspace (v/v) during the incubation, which signified that experimental conditions were conducive to denitrification activity. Amounts of $\mathrm{N}_{2} \mathrm{O}$ were significantly lower in the bacitracin treated soil at $500 \mathrm{mg} \cdot \mathrm{kg}^{-1}$ at the toeslope position, but not at the other topographic positions. Amounts of $\mathrm{N}_{2} \mathrm{O}$ produced in the roxarsoneand virginiamycin-treated soils were not significantly different than controls at any concentration tested (Figures 2(a)-(c)).

\subsection{Antibiotic Effects on Microbial Community Composition}

Total FAME concentrations in the control soils during the four week incubation remained constant at $366 \pm 56$ $\mathrm{mg} \cdot \mathrm{kg}^{-1}$, and were not significantly affected by any of the antibiotics at 1 or $100 \mathrm{mg} \cdot \mathrm{kg}^{-1}$.

Relative abundances of the 59 FAMEs were not significantly affected by bacitracin at 1 or $100 \mathrm{mg} \cdot \mathrm{kg}^{-1}$, or by roxarsone and virginiamycin at $1 \mathrm{mg}$ roxarsone $\mathrm{kg}^{-1}$ relative to the control. At the $100 \mathrm{mg} \cdot \mathrm{kg}^{-1}$ level, however, both roxarsone and virginiamycin significantly increased the abundances of $16: 1 \omega 7$ and $18: 1 \omega 7$ by $1.2-1.6$ times compared to the control during the incubation period.

\subsection{Sorption Effects Antibiotic Bioavailability}

Microbial growth in the zero level BT and AT solutions 


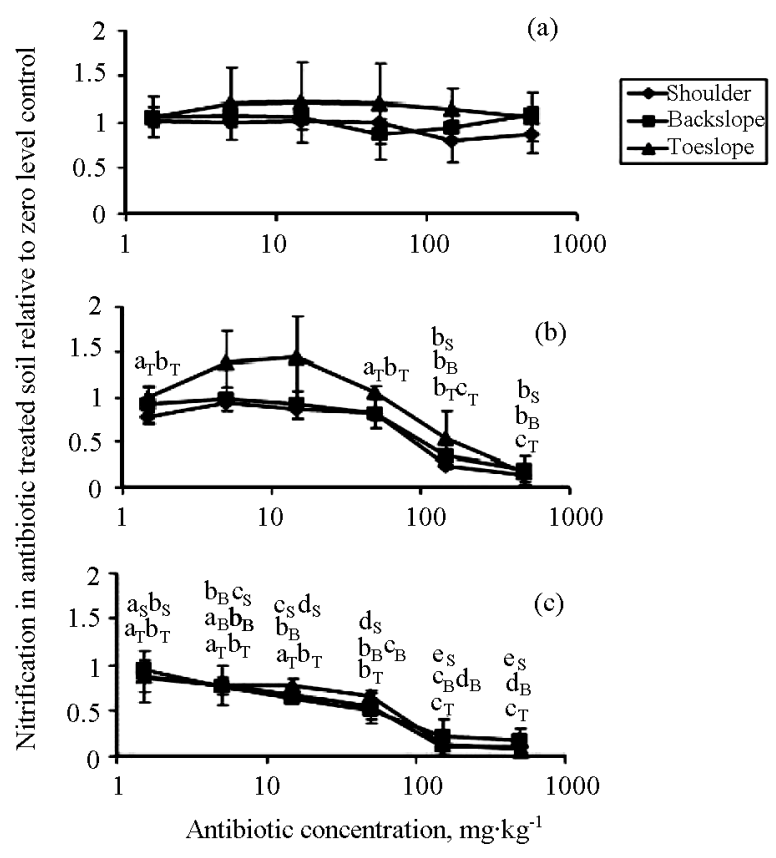

Figure 1. Effects of (a) bacitracin, (b) roxarsone, and (c) virginiamycin on nitrification in soils at three positions along a catena. Each value represents the mean of three field replicates \pm one standard deviation. Different lower case letters near the markers indicate that antibiotic significantly affected nitrification compared to the zero level control in the soils at the shoulder (S), backslope (B), and toeslope $(\mathrm{T})$ positions.

increased from initial optical densities at $600 \mathrm{~nm}$ of 0.16 \pm 0.02 to final values $0.37 \pm 0.03$ in $24 \mathrm{~h}$, which signified rapid growth potential of soil microorganisms under the experimental conditions.

In the BT treatments, microbial growth was not significantly affected by bacitracin at any concentration up to $300 \mathrm{mg} \cdot \mathrm{L}^{-1}$ (solid line in Figure 3(a)). Roxarsone and virginiamycin significantly inhibited microbial growth at $300 \mathrm{mg} \cdot \mathrm{L}^{-1}$ in the BT solutions, but they did not inhibit growth at any concentration in the AT solutions (dashed lines in Figures 3(b) and (c)).

\section{Discussion}

The poultry industry routinely incorporates bacitracin, roxarsone, and virginiamycin in feed at concentrations of $4-55,25-50$, and $5-22 \mathrm{mg} \cdot \mathrm{kg}^{-1}$, respectively [7]. A large fraction of antibiotics fed to the birds is excreted and accumulates in the litter, which is applied to soils at rates of $5 \mathrm{Mg}$ litter ha ${ }^{-1}$ for the unrelated purpose of improving soil fertility. Assuming litter is applied to a soil depth of $3 \mathrm{~cm}$, bacitracin, roxarsone, and virginiamycin concentrations in soil would be in the range of $0.07-1$ $\mathrm{mg} \cdot \mathrm{kg}^{-1}$. This is in the same concentration range indicated in other studies [8-10]. In this study, it was hy-

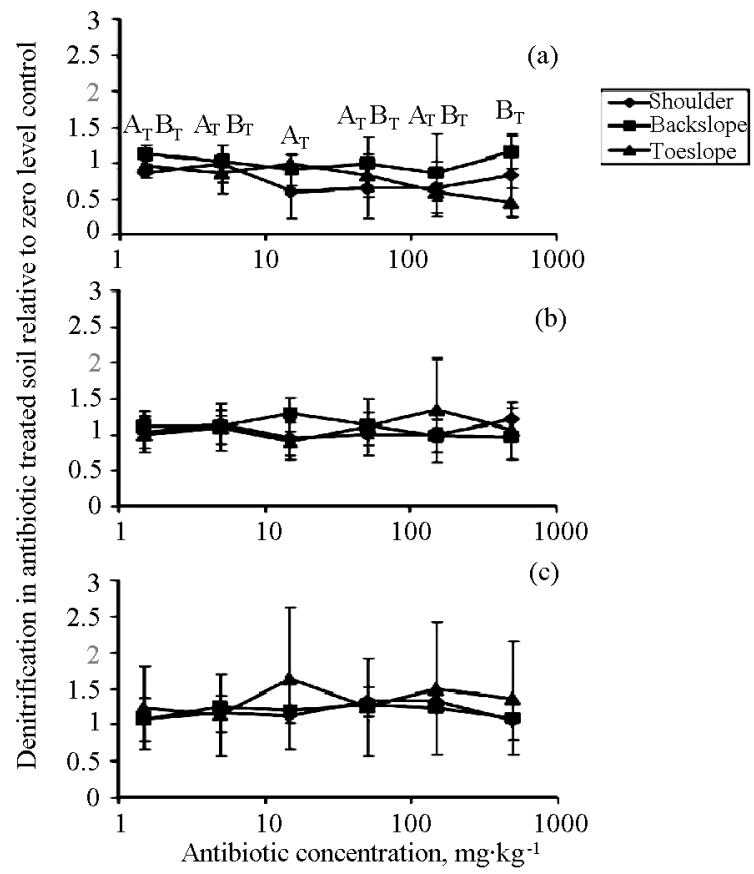

Figure 2. Effects of (a) bacitracin, (b) roxarsone, and (c) virginiamycin on denitrification in soils at three positions along a catena. Each value represents the mean of three field replicates \pm one standard deviation. Different lower case letters near the markers indicate that antibiotic significantly affected denitrification compared to the zero level control in soils at the shoulder (S), backslope (B), and toeslope $(T)$ positions.

pothesized that antibiotics at environmentally-relevant concentrations would have significant effects on microbial community composition and associated aerobic and anaerobic activities in soils, which so far have not been investigated for these three livestock antibiotics. The $\mathrm{N}$ transformation processes nitrification and denitrification were investigated because of their importance in plant nutrition and water quality.

Opposite to what was expected, none of the antibiotics added to soils at $1 \mathrm{mg} \cdot \mathrm{kg}^{-1}$ significantly influenced either the concentration of total FAMEs or the relative abundance of any specific FAMEs (total of 59 types) compared to zero level control soils during the four week exposure period. Moreover, bacitracin at the $100 \mathrm{mg} \cdot \mathrm{kg}^{-1}$ level did not affect microbial community composition. When roxarsone and virginiamycin were increased to $100 \mathrm{mg} \cdot \mathrm{kg}^{-1}$, however, microbial community composition of soils was significantly affected, as indicated by 1.2 - 1.6 fold increases in relative abundances of $16: 1 \omega 7$

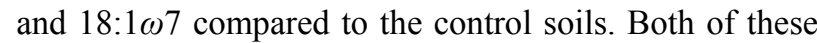
lipids are indicative of aerobic Gram-negative bacteria, so it appears that roxarsone and virginiamycin led to enrichments in members of this bacterial group. One possible explanation is that Gram-negative bacteria with these 


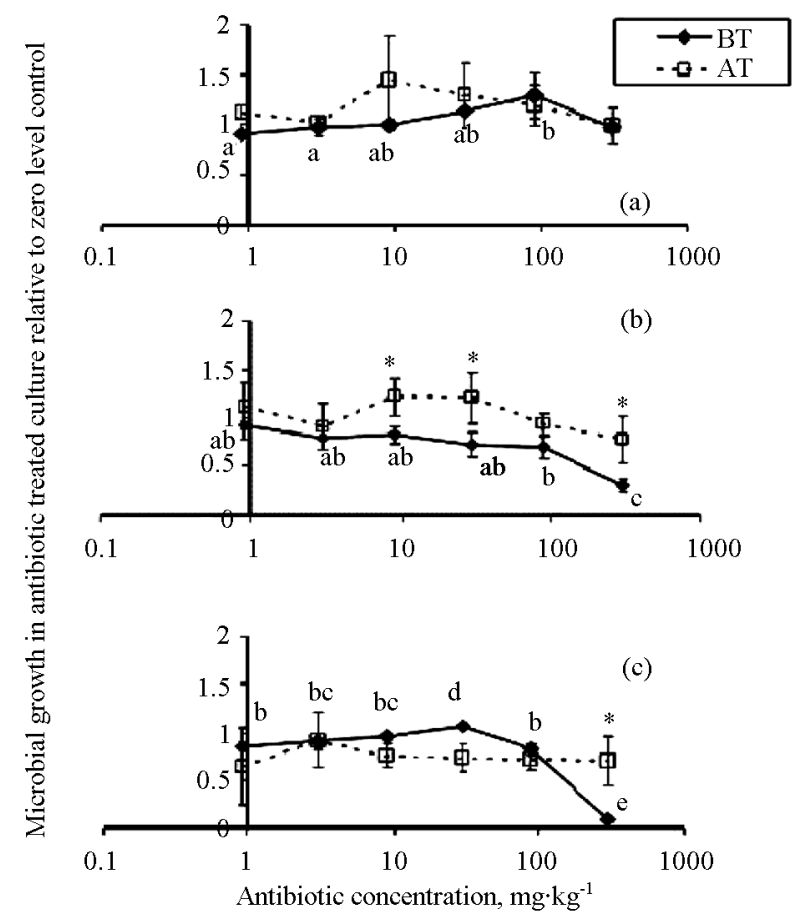

Figure 3. Microbial growth in cultures (measured as absorbance at $600 \mathrm{~nm}$ ) exposed to increasing concentrations of (a) bacitracin, (b) roxarsone, and (c) virginiamycin solutions, which were either first reacted with soil (AT) or not reacted with soil (BT). Each value represents the mean of three replicates \pm one standard deviation. Different lower case letters near the BT markers indicate that the antibiotic significantly affected microbial growth compared to the zero level control. The asterisks near the AT markers indicate that microbial growth was significantly different in the AT verses BT treatments.

two FAME biomarkers gained competitive advantages over other microbial groups in the soil, whose growth was curtailed by roxarsone and virginiamycin. Unfortunately, however, it was not possible to identify the antibiotic-sensitive groups from the FAME analysis.

Although roxarsone and virginiamycin at $100 \mathrm{mg} \cdot \mathrm{kg}^{-1}$ in the soil affected microbial community composition, it is unlikely that antibiotics would reach these levels in soils from poultry litter amendments, and so they would not likely have significant effects on microbial community composition. Furthermore, sorption would further decrease antibiotic concentrations in the bioavailable pool. As previously indicated, incorporation of $5 \mathrm{Mg} \cdot \mathrm{ha}^{-1}$ litter with typical antibiotic levels to the surface $3 \mathrm{~cm}$ of soil would increase antibiotic concentrations in soil to 0.1 - $1 \mathrm{mg} \cdot \mathrm{kg}^{-1}$. For the soils in this study, this equates to dissolved virginiamycin and roxarsone (bioavailable) concentrations of $0.0001-0.0005 \mathrm{mg} \cdot \mathrm{L}^{-1}$, which was calculated from the sorption isotherm models in Figure 4. These concentrations are several orders of magnitude lower than dissolved levels that affected microbial com-

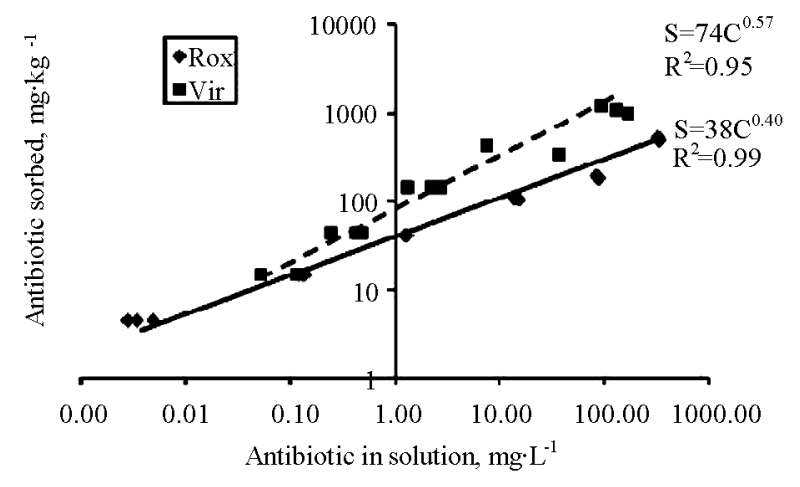

Figure 4. Sorption isotherms for roxarsone and virginiamycin for soils used in the study. Sorption models could not be determined for bacitracin, because all of the antibiotic added to the soil-water mixture was removed from soil solution during the incubation (complete retention of the antibiotic).

munity composition in this study $\left(100 \mathrm{mg} \cdot \mathrm{kg}^{-1}\right.$ soil equates to $2 \mathrm{mg} \cdot \mathrm{L}^{-1}$ virginiamycin and $11 \mathrm{mg} \cdot \mathrm{L}^{-1}$ roxarsone in soil solution).

Results from the nitrification and denitrification experiments were generally consistent with those discussed above. Specifically, roxarsone and virginiamycin significantly inhibited nitrification in the soils, but only at concentrations that were much higher than would be expected in litter-amended soils. For example, roxarsone inhibited nitrification at $\geq 150 \mathrm{mg} \cdot \mathrm{kg}^{-1}$ (corresponding to $\geq 31 \mathrm{mg} \cdot \mathrm{L}^{-1}$ in soil solution), virginiamycin inhibited nitrification at $\geq 15 \mathrm{mg} \cdot \mathrm{kg}^{-1}$ (corresponding to $\geq 0.06$ $\mathrm{mg} \cdot \mathrm{L}^{-1}$ in soil solution), and bacitracin did not affect nitrification at any concentration up to $500 \mathrm{mg} \cdot \mathrm{kg}^{-1}$. Denitrification was inhibited by bacitracin at $500 \mathrm{mg} \cdot \mathrm{kg}^{-1}$, but the anaerobic process was not affected by roxarsone or virginiamycin at any concentration tested. These results indicated that neither nitrification nor denitrification activities would likely be affected by additions of poultry litter with typical antibiotic levels to these soils. In other soils that do not retain virginiamycin to the same extent as those in this study, however, it is possible virginiamycin levels in solution from poultry litter additions could exceed $0.06 \mathrm{mg} \cdot \mathrm{L}^{-1}$, which would be high enough to inhibit nitrification.

To our knowledge, no other studies have determined the effects of bacitracin, virginiamycin, or roxarsone on microbial community composition in soils; several studies, however, have evaluated the effects of these antibiotics on microorganisms in the gastrointestinal tract of broilers. For example, the microbiota composition in the gastrointestinal tract of broilers was altered when birds were fed bacitracin at $28 \mathrm{mg} \cdot \mathrm{kg}^{-1}$ [6], virginiamycin at 20 $\mathrm{mg} \cdot \mathrm{kg}^{-1}$ [25], and a combination of roxarsone, bacitracin, virginiamycin and nicarbazin at 45, 50, 10, and 113 
$\mathrm{mg} \cdot \mathrm{kg}^{-1}$, respectively [26]. It is unlikely that microorganisms in soils would be exposed to these high concentrations from litter applications, due to dilution and sorption.

There are several other possible explanations besides low bioavailable concentrations for why bacitracin, virginiamycin, and roxarsone did not have large effects on microbial community composition and activities in soils of this study, including 1) intrinsic resistance/insensitivity to antibiotics [27-33]; 2) degradation of antibiotics [34-36]; and 3) sorption/complexation of antibiotics to soil surfaces $[8-10,17,18]$.

To explore the importance of intrinsic resistance/insensitivity, microorganisms were extracted from soil and grown in soil-free LB cultures with increasing concentrations of antibiotics (BT solutions). Results showed that microbial growth was not inhibited until antibiotic concentrations reached $300 \mathrm{mg} \cdot \mathrm{L}^{-1}$.

The capacity for soil microorganisms to proliferate at such high antibiotic concentrations observed in this study indicated that at least some were intrinsically resistant/insensitive to these antibiotics. On the one hand, these results were surprising considering that the soil microorganisms used in the study were never exposed to poultry litter or these antibiotics. On the other hand, however, results were in-line with studies that showed native microbial populations from pristine soils were resistant to diverse types of antibiotics, presumably as survival strategies in resource-competitive environments where antibiotics are naturally produced [27,28].

Possible mechanisms of antibiotic resistance included 1) low permeability of cell membrane to antibiotics (particularly in Gram-negative bacteria); 2) efflux of antibiotics out of the cell; 3 ) site alteration of antibiotic target site, and 4) enzymatic inactivation of the antibiotic [31]. Many of these mechanisms are attributed to chromosome- or plasmid-bound genes that can be transferred between bacteria in different phylogenetic groups by horizontal gene transfer processes such as transformation, transduction, and conjugation [37]. One or more of these mechanisms could account for intrinsic resistance/insensitivity to antibiotics by soil microorganisms observed in this study.

\section{Conclusion}

Results from this study showed that bacitracin, roxarsone, and virginiamycin had limited effects on microbial growth, community composition, nitrification, and denitrification at environmentally-relevant concentrations that would be expected in poultry litter-amended soils. This was mostly attributed to intrinsic antibiotic resistance/insensitivity of the native soil community and antibiotic sorption to soils, which protected microorganisms against high concentrations of antibiotics. Future studies should evaluate the concentrations, fate, and ecological effects of other prevalent pharmaceuticals in biosolid wastes and soil environments.

\section{Acknowledgements}

We appreciate the assistance of the Georgia Zeigler and the Soil Testing Laboratory at the University of Kentucky Division of Regulatory Services for the chemical analysis of the soils used in this study.

\section{REFERENCES}

[1] M. Mellon, C. Benbrook and K. L. Benbrook, "Hogging It: Estimates of Antimicrobial Abuse in Livestock," Union of Concerned Scientists, Cambridge, 2001. http://www.ucsusa.org/assets/documents/food_and_agric ulture/hog_chaps.pdf

[2] K. Kümmerer, "Significance of Antibiotics in the Environment," Journal of Antimicrobial Chemotherapy, Vol. 52, 1, 2003, pp. 5-7. doi:10.1093/jac/dkg293

[3] A. K. Sarmah, M. T. Meyer and A. B. A Boxall, "A Global Perspective on the Use, Sales, Exposure Pathways, Occurrence, Fate and Effects of Veterinary Antibiotics in the Environment," Chemosphere, Vol. 65, No. 5, 2006, pp. 725-759. doi:10.1016/i.chemosphere.2006.03.026

[4] R. A. Swick, "Role of Growth Promotents in Poultry and Swine Feed," ASA Technical Bulletin, Vol. AN04, 1996. www.asaimsea.com/pdfs/AN04-swick.pdf

[5] P. Butaye, L. A. Deviese and F. Haesebrouck, "Antimicrobial Growth Promoters Used in Animal Feed: Effects of Less Well-Known Antibiotics on Gram-Positive Bacteria," American Society for Microbiology, Vol. 16, No. 2, 2003, pp. 175-188. doi:10.1128/CMR.16.2.175-188.2003

[6] A. A. Pedroso, J. F. Menten, M. R. Lambais, A. M. Racanicci, F. A. Longo and J. O. Sorbara, "Intestinal Bacterial Community and Growth Performance of Chickens Fed Diets Containing Antibiotics," Poultry Science, Vol. 85, No. 4, 2006, pp. 747-752.

[7] H. D. Chapman and Z. B. Johnson, "Use of Antibiotics and Roxarsone in Broiler Chickens in the USA: Analysis for the Years 1995 to 2000," Poultry Science, Vol. 81, No. 3, 2002, pp. 356-364.

[8] S. Thiele-Bruhn, "Pharmaceutical Antibiotic Compounds in Soils-A Review," Journal of Plant Nutrition, Vol. 166, No. 2, 2003, pp. 145-16. doi:10.1002/jpln.200390023

[9] B. Halling-Sørensen, S. N. Nielsen, P. F. Lanzky, F. Ingerslev, H. C. H. Lutzhoft and S. E. Jorgensen, "Occurrence, Fate and Effects of Pharmaceutical Substances in the Environment-A Review," Chemosphere, Vol. 36, No. 2, 1998, pp. 357-394. doi:10.1016/S0045-6535(97)00354-8

[10] K. Kim, G. Owens, S. Kwon, K. So, D. Lee and Y. S. Ok, "Occurrence and Environmental Fate of Veterinary Anti- 
biotics in the Terrestrial Environment," Water Air Soil Pollution, Vol. 214, No. 1-4, 2011, pp. 163-174. doi:10.1007/s11270-010-0412-2

[11] C. Colinas, E. Ingham and R. Molina, "Population Responses of Target and Nontarget Forest Soil Organisms to Selected Biocides," Soil Biology \& Biochemistry, Vol. 26, No. 1, 1994, pp. 41-47. doi:10.1016/0038-0717(94)90193-7

[12] K. Westergaard, A. K. Muller, S. Christensen, J. Bloem and S. J. Sorensen, "Effects of Tylosin as a Disturbance on the Soil Microbial Community," Soil Biology \& Biochemistry, Vol. 33, No. 15, 2001, pp. 2061-2071. doi:10.1016/S0038-0717(01)00134-1

[13] D. K. Patten, D. C. Wolf, W. E. Kunkle and L. W. Douglas, "Effect of Antibiotics in Beef Cattle Feces on Nitrogen and Carbon Mineralization in Soil and on Plant Growth and Composition," Journal of Environmental Quality, Vol. 9, No. 1, 1980, pp. 167-172. doi:10.2134/jeq1980.00472425000900010035x

[14] F. Liu, G. Ying, R. Tao, J. Zhao, J. Yang and L. Zhao, "Effects of Six Selected Antibiotics on Plant Growth and Soil Microbial and Enzymatic Activities," Environmental Pollution, Vol. 157, No. 5, 2009, pp. 636-1642. doi:10.1016/i.envpol.2008.12.021

[15] S. Thiele-Bruhn and I. C. Beck, "Effects of Sulfonamide and Tetracycline Antibiotics on Soil Microbial Activity and Microbial Biomass," Chemosphere, Vol. 59, No. 4, 2005, pp. 457-465. doi:10.1016/i.chemosphere.2005.01.023

[16] D. Pramer, "The Persistence and Biological Effects of Antibiotics in Soil," Journal of Applied Microbiology, Vol. 6, No. 3, 1958, pp. 221-224.

[17] B. Chu, K. W. Goyne, S. H. Anderson, C. H. Lin and R. P. Udawatta, "Veterinary Antibiotic Sorption to Agroforestry Buffer, Grass Buffer, and Cropland Soils," Agroforestry Systems, Vol. 79, No. 1, 2010, pp. 67-80. doi:10.1007/s10457-009-9273-3

[18] B. L. Brown, A. D. Slaughter and M. E. Schreiber, "Controls on Roxarsone Transport in Agricultural Watersheds," Applied Geochemistry, Vol. 20, No. 1, 2005, pp. 123-133. doi:10.1016/j.apgeochem.2004.06.001

[19] A. Mehlich, "Mehlich 3 Soil Test Extractant: A Modification of Mehlich 2 Extractant," Communications in Soil Science and Plant Analysis, Vol. 15, No. 12, 1984, pp. 1409-1416. doi:10.1080/00103628409367568

[20] W. R. Howarth and E. A. Paul, "Microbial Biomass," In: Weaver, et al., Eds., Soil Analysis, Part 2: Microbiological and Biochemical Properties, SSSA Book Series No. 5. Madison, 1994, pp. 753-773.

[21] J. D. Crutchfield and H. R. Burton, "Improved Methods for the Quantification of Nitrate in Plant Materials," Analytical Letters, Vol. 22, No. 3, 1998, pp. 555-571. doi: $10.1080 / 00032718908051349$

[22] J. R. White and K. R. Reddy, "Influence of Nitrate and Phosphorus Loading on Denitrifying Enzyme Activity in Everglades's Wetland Soils," Soil Science Society of America Journal, Vol. 63, No. 6, 1999, pp. 1945-1954.

\section{doi:10.2136/sssaj1999.6361945x}

[23] M. E. Schutter and R. P. Dick, "Comparison of Fatty Acid Methyl Ester (FAME) Methods for Characterizing Microbial Communities," Soil Science Society of America Journal, Vol. 64, No. 5, 2000, pp. 1659-1668. doi:10.2136/sssaj2000.6451659x

[24] E. M. D'Angelo, A. D. Karathanasis, E. J. Sparks, S. A. Ritchey and S. A. Wehr-McChesney, "Soil Carbon and Microbial Communities at Mitigated and Late Successional Bottomland Forest Wetlands," Wetlands, Vol. 25, No. 1, 2005, pp. 162-175. doi:10.1672/0277-5212(2005)025[0162:SCAMCA]2.0.C $\mathrm{O} ; 2$

[25] T. J. Dumonceaux, J. E. Hill, S. M. Hemmingsen and A. G. Van Kessel, "Characterization of Intestinal Microbiota and Response to Dietary Virginiamycin Supplementation in the Broiler Chicken," Applied and Environmental Microbiology, Vol. 72, No. 4, 2006, pp. 2815-2823. doi:10.1128/AEM.72.4.2815-2823.2006

[26] M. G. Wise and G. R. Siragusa, "Quantitative Analysis of the Intestinal Bacterial Community in One- to ThreeWeek-Old Commercially Reared Broiler Chickens Fed Conventional or Antibiotic-Free Vegetable-Based Diets," Journal of Applied Microbiology, Vol. 102, No. 4, 2007, pp. 1138-1149. doi:10.1111/j.1365-2672.2006.03153.X

[27] H. K. Allen, J. Donato, H. H. Wang, K. A. Cloud-Hansen, J. Davies and J. Handelsman, "Call of the Wild: Antibiotic Resistance Genes in Natural Environments," Nature Reviews Microbiology, Vol. 8, No. 4, 2010, pp. 251-259. doi:10.1038/nrmicro2312

[28] V. M. D'Costa, E. Griffiths and G. D. Wright, "Expanding the Soil Antibiotic Resistome: Exploring Environmental Diversity," Current Opinion in Microbiology, Vol. 10, No. 5, 2007, pp. 481-489. doi:10.1016/j.mib.2007.08.009

[29] N. Esiobu, L. Armenta and J. Ike. "Antibiotic Resistance in Soil and Water Environments," International Journal of Environmental Health Research, Vol. 12, No. 2, 2002, pp. 133-144. doi:10.1080/09603120220129292

[30] C. W. Knapp, J. Dolfing, P. A. Ehlert and D. W. Graham, "Evidence of Increasing Antibiotic Resistance Gene Abundances in Archived Soils Since 1940," Environmental Science \& Technology, Vol. 44, No. 2, 2010, pp. 580-587. doi:10.1021/es901221x

[31] D. Mazel and J. Davies, "Antibiotic Resistance in Microbes," Cellular and Molecular Life Sciences, Vol. 56, No. 9-10, 1999, pp. 742-754. doi: $10.1007 / \mathrm{s} 000180050021$

[32] E. C. Oldfield, "The Road to Resistance: Antibiotics as Growth Promoters for Animals," World Literature Review, Vol. 98, No. 2, 2003, p. 499. doi:10.1111/j.1572-0241.2003.07277.x

[33] L. Onan and T. LaPara, "Tylosin-Resistant Bacteria Cultivated from Agricultural Soil," FEMS Microbiology Letters, Vol. 220, No. 1, 2003, pp. 15-20. doi:10.1016/S0378-1097(03)00045-4

[34] J. Gavalchin and S. E. Katz, "The Persistence of Fe- 
cal-Borne Antibiotics in Soil," Journal of the Association of Official Analytical Chemists, Vol. 77, No. 2, 1994, pp. 481-485.

[35] F. Ingerslev and B. Halling-Sørrensen, "Biodegradability of Metronidazole, Olaquindox, and Tylosin and Formation of Tylosin Degradation Products in Aerobic SoilManure Slurries," Ecotoxicology and Environmental Safety, Vol. 48, No. 3, 2001, pp. 311-320. doi:10.1006/eesa.2000.2026
[36] C. A. Weerasinghe and D. Towner, "Aerobic Biodegradation of Virginiamycin in Soil," Environmental Toxicology and Chemistry, Vol. 16, No. 9, 1997, pp. 1873-1876. doi:10.1002/etc.5620160916

[37] J. Davison, "Genetic Exchange between Bacteria in the Environment," Plasmid, Vol. 42, No. 2, 1999, pp. 73-91. doi:10.1006/plas.1999.1421 